\title{
Polymorphism of the H-FABP, MC4R and ADD1 genes in the Meishan and four other pig populations in China
}

\author{
C.L. $\mathrm{Li}^{1,2}$, Y.C. Pan ${ }^{1 \#}$ and H. Meng \\ ${ }^{1}$ Department of Animal Science, School of Agriculture and Biology, Shanghai Jiaotong University, \\ Shanghai 201101, P.R. China \\ ${ }^{2}$ School of Pharmacy, East China University of Science and Technology, Shanghai 200237, P.R. China
}

\begin{abstract}
Genes such as the Heart Fatty Acid-Binding Protein (H-FABP), the Melanocortin-4 Receptor (MC4R) and the Adipocyte Determination and Differentiation factor-1 (ADD1) play an important role in meat quality in pigs. The Meishan is one of the most prolific pig breeds in the world, but it is in danger, in China, of being replaced by other exotic pig breeds because of its slow growth rate and high body fat content. To know their present genetic status, the polymorphism of the three genes in the Meishan and four other pig populations (Sutai, Yorkshire $\times$ Sutai, Landrace $\times$ Sutai and Duroc $\times$ Landrace $\times$ Yorkshire) in China was analysed, using PCR-RFLP and PCR-SSCP, and were further compared with each other. The results showed that gene and genotype frequencies differed significantly between the Meishan and the other four populations. This is suggested to be one of the reasons for the good meat quality of the Meishan compared to the other breeds. In addition, since half of the genetic background of Sutai is from the Meishan, results also indicated that marker assisted selection (MAS) is very important for the development of new pig breeds.
\end{abstract}

Keywords: Polymorphism, H-FABP, MC4R, ADD1, Meishan

${ }^{\#}$ Corresponding author. E-mail: panyc@sjtu.edu.cn

\section{Introduction}

In the past decades the main focus of pig breeders has been on growth rate, feed conversion efficiency and reproductive performance, with less concerned about meat quality such as meat colour, $\mathrm{pH}$, drip loss, intramuscular fat content, tenderness, back fat thickness, etc. This is partially due to the difficulty in improving these type of traits through traditional quantitative genetics. However, the development of molecular genetics this is changing, because many candidate genes have been identified which could be used to improve pork quality through marker assisted selection (MAS) (Dekkers, 2004).

The Heart Fatty Acid-Binding Protein (H-FABP) gene encodes a type of cytosol protein that transports fatty acids from the cell membrane to other sites where 3-acyl-glyceride and phospholipids are synthesized and fatty acids are oxidized. Moreover, H-FABP promotes cells to absorb fatty acids by combining with fatty acids in vivo (Frand et al., 1998). Gerbens et al. (1997; 1999; 2000) discovered Msp I, Hae II and Hinf I polymorphism of the H-FABP gene that is related to intramuscular fat content. Lin et al. (2002) analysed the polymorphism of the H-FABP gene in 10 pig breeds, including six native Chinese breeds and four other breeds. No Msp I and Hae III polymorphism was found in the six native Chinese pig breeds. Melanocortin-4 Receptor (MC4R) is believed to be a link between feed intake and body weight (Seeley et al., 1997). Polymorphism of the MC4R gene has been reported to be associated with back fat thickness (Kim et al., 1998). Adipocyte Determination and Differentiation factor-1 (ADD1) can activate or restrain some genes in fat and glucose metabolism (Foretz et al., 1999; Hitoshi, 2001), which include the low-density lipoprotein receptor (LDLR) (Brown et al., 1997), acetyl-CoA cartboxyiase (ACC) (Foretz et al., 1999), phosphoenolpyruvate carboxykinase (PEPCK) (Chakravarty et al., 2001), fatty acids synthase (FAS) (Soazig et al., 2002), lipoprotein lipase (LPL) (Chakravarty et al., 1993) and others. Research has suggested that the ADD1 gene can be used as a candidate gene for pork quality (Rebcca et al., 2000).

The Meishan breed is renowned for its prolificacy and good meat qualities. It has contributed substantially to pork production and the development of new breeds, and this is sure to continue in future. However, only a small population is presently being conserved. Furthermore, we do not know the status of favourable genes in the breed. The Sutai is a breed that has been developed by The Breeding Centre of Taihu 
Pig in China from a cross between the Duroc (50\%) and the Meishan (50\%). It has taken about 20 years to select for low back-fat thickness, improved growth rate and an improved feed conversion efficiency. The method used in the development of the Sutai breed was the traditional selection method. However, it is important to know whether the traditional selection method can concentrate favourable genes as successfully as the MAS method. Presently the Sutai is used mainly as a maternal line to cross with Landrace or Yorkshire boars for the production of commercial pigs that compete mainly with the Duroc $\times$ Landrace $\times$ Yorkshire cross in the pork market of China.

In view of the three genes playing an important role in meat quality, this project was conducted to investigate and compare the polymorphism of these genes in the Meishan and four other pig populations, the Sutai, Landrace $\times$ Sutai, Yorkshire $\times$ Sutai, Duroc $\times$ Landrace $\times$ Yorkshire, to obtain information which would assist in their conservation and selection.

\section{Materials and Methods}

Ninety three individuals were randomly selected from five herds as an experimental sample, and included 18 Meishan (M), 21 Sutai (S), 14 Yorkshire $\times$ Sutai (YS), 16 Landrace $\times$ Sutai (LS) and 24 Duroc $\times$ Landrace $\times$ Yorkshire (DLY) pigs.

The DNA was isolated by the standard methods (Cold Spring Harbor), viz. ca. $10 \mathrm{mg}$ of ear tissue was put into an eppendorff tube and washed with $1 \mathrm{~mL}$ PBS. $12 \mu \mathrm{L}$ proteinase $\mathrm{K}(0.2 \mathrm{mg} / \mathrm{mL})$ and $600 \mu \mathrm{L} .10 \%$ SDS were added to the tube. The tube was shaken gently, and incubated overnight at $55{ }^{\circ} \mathrm{C}$ in a waterbath. $1.2 \mu \mathrm{L}$ Rnase A $(10 \mathrm{mg} / \mathrm{mL})$ was added to the same tube and incubated at $37^{\circ} \mathrm{C}$ in a waterbath. $600 \mu \mathrm{L}$ phenol was added, shaken by hand for $10 \mathrm{~min}$ and centrifuged at $10000 \mathrm{rpm}$ for $10 \mathrm{~min}$. The supernatant was pipetted into a new tube, $300 \mu \mathrm{L}$ phenol and $300 \mu \mathrm{L}$ chloroform/isoamyl alcohol (24:1) were added, shaken by hand for $10 \mathrm{~min}$, and centrifuged at $10000 \mathrm{rpm}$ for $10 \mathrm{~min}$. The supernatant was pipetted into a new tube, and $600 \mu \mathrm{L}$ chloroform/isoamyl alcohol $(24: 1)$ was added, shaken by hand for $10 \mathrm{~min}$, and centrifuged at $10000 \mathrm{rpm}$ for $10 \mathrm{~min}$. The supernatant was pipetted into a new tube, $1 \mathrm{~mL}$ frozen ethanol was added and shaken gently until the DNA precipitated. It was then centrifuged at $10000 \mathrm{rpm}$ for $10 \mathrm{~min}$. The DNA was washed in $70 \%$ ethanol and dried at room temperature. The DNA was dissolved in $50 \mu \mathrm{L}$ sterile water for five hours (or longer if necessary) at $55{ }^{\circ} \mathrm{C}$ in a waterbath. The DNA concentration was measured in a spectrophotometer and stored at $4{ }^{\circ} \mathrm{C}$ (Sambrook et al., 2002).

The characteristics of the H-FABP, MC4R and ADD1 genes were analysed according to the methods of Gerbens et al. (1997), Kim et al. (1998) and Li et al. (Unpublished), respectively. All data were analysed statistically using the $\chi^{2}$ method (Du, 2003) and the FREQ procedures of SAS (1994).

All primers were synthesized as shown in Table 1. The PCR reaction was run in a thermocycler (MJ, USA). The PCR reaction mixture (total of $30 \mu \mathrm{L}$ ) contained $100 \mathrm{ng}$ of genomic DNA, $3 \mu \mathrm{L}$ of $10 \times \mathrm{PCR}$ buffer, $10 \mathrm{pmol}$ of each primer, $170 \mu \mathrm{M}$ of dNTPs and $1.0 \mathrm{U}$ of Taq polymerase (TaKaRa Biotech, China). The cycling profile was: $94{ }^{\circ} \mathrm{C}(4 \mathrm{~min}) 1 \mathrm{cycle}, 94{ }^{\circ} \mathrm{C}(30 \mathrm{sec}), 55-60{ }^{\circ} \mathrm{C}(30 \mathrm{~s}), 72{ }^{\circ} \mathrm{C}(1 \mathrm{~min}) 30$ cycles, 72 ${ }^{\circ} \mathrm{C}(10 \mathrm{~min}) 1$ cycle. The amplified products of H-FABP and MC4R genes were digested with restriction enzymes Taq I and Hae III (Huamei Biotech, China). The digested PCR fragments were analysed on 2\% agarose gels.

Table 1 Primer sequences of H-FABP, MC4R and ADD1 genes

\begin{tabular}{ccccc}
\hline \multirow{2}{*}{ Gene } & $\begin{array}{c}\text { Analytical } \\
\text { technique }\end{array}$ & \multicolumn{1}{c}{ Primer sequence } & $\begin{array}{c}\text { Annealing } \\
\text { temperature }\end{array}$ & References \\
\hline H-FABP & PCR-RFLP & 5'-ATTGCTTCGGTGTGTTTGAG -3' & $60{ }^{\circ} \mathrm{C}$ & Gerbens et al., 1997 \\
& & 5'-TCAGGAATGGGAGTTATTGG-3' & & \\
MC4R & PCR-RFLP & $\begin{array}{l}\text { 5'-TACCCTGACCATCTTGATTG -3' } \\
\text { 5'-ATAGCAACAGATGATCTCTTG-3' }\end{array}$ & $58{ }^{\circ} \mathrm{C}$ & Kim et al., 2000 \\
ADD1 & PCR-SSCP & $\begin{array}{l}\text { 5'-GGTAGTGGACACTGACAAGCT-3' } \\
\text { 5'-GCTTAGCTCAACAGACGGAG-3' }\end{array}$ & $55^{\circ} \mathrm{C}$ & Li et al., \\
& & & Unpublished results \\
\hline
\end{tabular}

H-FABP - Heart Fatty Acid-Binding Protein

MC4R - Melanocortin-4 Receptor

ADD1 - Adipocyte Determination and Differentiation factor-1 
The amplified products of ADD1 were mixed with single strand conformation polymorhism (SSCP) buffer, $0.1 \%$ bromophenol blue and $0.1 \%$ xylene cyanole in formamide. Before being loaded into the gel the samples were denaturized for $5 \mathrm{~min}$ at $95{ }^{\circ} \mathrm{C}$ and kept on ice for $5 \mathrm{~min}$. Then $10 \mu \mathrm{L}$ of this mixture was applied to a $9 \%$ polyacrylamide gel (49:1 acrylamide:bis), $10 \%(\mathrm{~V} / \mathrm{V})$ glycerol and a $0.5 \times \mathrm{TBE}$ buffer. Electrophoresis was run overnight at room temperature. The gel was then stained with silver nitrate according to a standard protocol, as follows: The gel was washed in $10 \%$ ethanol for 15 min and then transferred to $1 \% \mathrm{HNO}_{3}$ for $10 \mathrm{~min}$. Next, the gel was incubated for $30 \mathrm{~min}$ in $0.2 \%$ silver nitrate with the addition of formaldehyde (the final concentration of formaldehyde was $0.12 \%$ ). The developing reaction ( $c a$. 20-30 $\mathrm{min}$ ) was performed with the use of 3\% sodium carbonate with the addition of formaldehyde (the final concentration of formaldehyde was $0.05 \%$ ) and stopped, using $10 \%$ acetic acid.

\section{Results and Discussion}

H-FABP gene: The PCR-RFLP result of the H-FABP gene is shown in Figure 1 where the AA genotype has $683 \mathrm{bp}$ and $117 \mathrm{bp}$ fragments, the BB genotype has $405 \mathrm{bp}, 278 \mathrm{bp}$ and $117 \mathrm{bp}$ fragments and the AB genotype has $683 \mathrm{bp}, 405 \mathrm{bp}, 278 \mathrm{bp}$ and $117 \mathrm{bp}$ fragments. The reported genotypes AA, BB and AB also contained $16 \mathrm{bp}$ fragments that could not be detected (not scored) when using this technique.

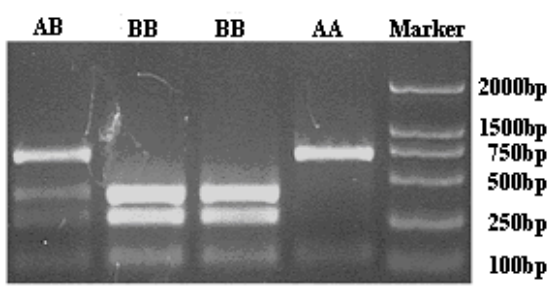

Fig. 1 RFLP analysis on PCR amplification to H-FABP gene

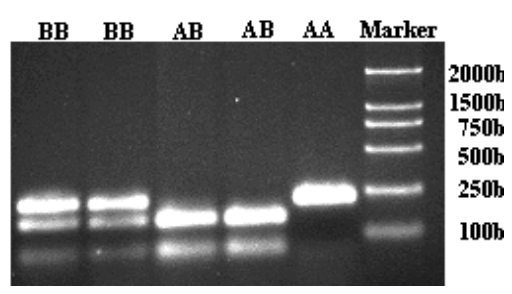

Fig. 2 RFLP analysis on PCR amplification to MC4R gene

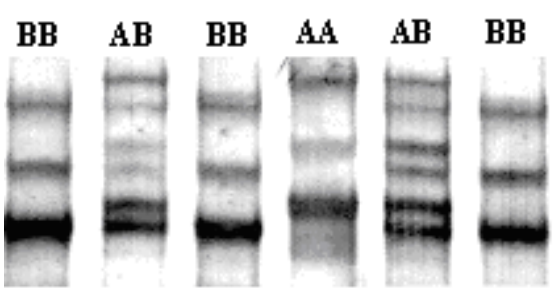

Fig. 3 SSCP analysis on PCR amplification to ADD1 gene

The frequencies of the H-FABP gene and genotype are shown in Table 2 and the results of the $\chi^{2}$ test between populations in Table 3 . The frequencies differed significantly $(\mathrm{P}<0.01)$ between the five populations. Furthermore, the frequencies of the H-FABP gene and genotype of the Meishan differed significantly $(\mathrm{P}<0.01)$ from the other four populations, while the frequencies of the H-FABP gene and genotype of Sutai were different $(\mathrm{P}<0.01)$ from those of the Landrace $\times$ Sutai and Duroc $\times$ Landrace $\times$ Yorkshire populations. The frequencies of the H-FABP gene and genotype did not differ between the latter three populations. The decrease in the frequency of the A allele from $100 \%$ in the Meishan to $71.5 \%$ in the Sutai reflects its origin as a cross between the Meishan and Duroc.

Table 2 The H-FABP gene and genotype frequencies in the Meishan and four other pig populations in China

\begin{tabular}{|c|c|c|c|c|c|c|c|c|c|c|}
\hline \multirow{2}{*}{ Population } & \multirow{2}{*}{$\mathrm{n}$} & \multicolumn{3}{|c|}{ Genotype Freq. (\%) } & \multirow{2}{*}{$\chi^{2}$} & \multirow{2}{*}{$\chi_{0.01(8)}^{2} *$} & \multicolumn{2}{|c|}{ Gene Freq. (\%) } & \multirow{2}{*}{$\chi^{2}$} & \multirow{2}{*}{$\chi_{0.01(4)}^{2}{ }^{*}$} \\
\hline & & $\overline{\mathrm{AA}}$ & $\mathrm{AB}$ & BB & & & $\mathrm{A}$ & B & & \\
\hline $\mathrm{M}$ & 18 & 100.0 & 0 & 0 & & & 100.00 & 0 & & \\
\hline $\mathrm{S}$ & 21 & 62.0 & 19.0 & 19.0 & & & 71.50 & 28.50 & & \\
\hline LS & 16 & 18.8 & 37.5 & 43.7 & $41.56^{* *}$ & 20.09 & 37.55 & 62.45 & $51.99^{* *}$ & 13.28 \\
\hline YS & 14 & 28.6 & 35.7 & 35.7 & & & 46.45 & 53.55 & & \\
\hline DLY & 24 & 12.5 & 33.3 & 54.2 & & & 29.15 & 70.85 & & \\
\hline
\end{tabular}

M - Meishan; S - Sutai; LS - Landrace $\times$ Sutai; YS - Yorkshire $\times$ Sutai; DLY - Duroc $\times$ Landrace $\times$ Yorkshire

$* \chi_{\alpha(d f)}^{2}$ is the $\chi^{2}$ value where $\alpha$ is the level of significance and $d f$ degrees of freedom

$* *$ mean frequencies differ significantly $(\mathrm{P}<0.01)$ 
MC4R gene: The result of PCR-RFLP of the MC4R gene is shown in Figure 2, where the AA genotype has a $226 \mathrm{bp}$ fragment, the $\mathrm{BB}$ genotype has $226 \mathrm{bp}, 156 \mathrm{bp}$ and $70 \mathrm{bp}$ fragments and the $\mathrm{AB}$ genotype has $156 \mathrm{bp}$ and $70 \mathrm{bp}$ fragments.

Table 3 The $\chi^{2}$ test of the H-FABP gene and genotype frequencies in the Meishan and four other pig populations

\begin{tabular}{|c|c|c|c|c|c|c|c|c|}
\hline \multirow{2}{*}{ Population } & \multicolumn{4}{|c|}{ Genotype frequency } & \multicolumn{4}{|c|}{ Gene frequency } \\
\hline & $\mathrm{S}$ & LS & YS & DLY & $\mathrm{S}$ & LS & YS & DLY \\
\hline $\mathrm{M}$ & $8.60 *$ & $23.65^{* *}$ & $18.69^{* *}$ & $31.50^{* *}$ & $10.03^{* *}$ & $28.90^{* *}$ & $22.28 * *$ & $39.97 * *$ \\
\hline $\mathrm{S}$ & & $6.93 *$ & 3.75 & $12.24 * *$ & & $7.20^{* *}$ & 3.46 & $14.43 * *$ \\
\hline LS & & & 0.43 & 0.51 & & & 0.19 & 0.29 \\
\hline YS & & & & 1.90 & & & & 1.62 \\
\hline
\end{tabular}

M - Meishan; S - Sutai; LS - Landrace $\times$ Sutai; YS - Yorkshire $\times$ Sutai; DLY - Duroc $\times$ Landrace $\times$ Yorkshire

$*$ mean frequencies differ at $\mathrm{P}<0.05 ; * *$ mean frequencies differ at $\mathrm{P}<0.01$

$\chi^{2}$ values at 0.05 or 0.01 levels of significance with different degree of freedoms are as follows:

$\chi_{0.05(2)}^{2}=5.99 ; \chi_{0.01(2)}^{2}=9.21 ; \chi_{0.05(1)}^{2}=3.84 ; \chi_{0.01(2)}^{2}=6.63$

Table 4 The MC4R gene and genotype frequencies in the Meishan and four other pig populations in China

\begin{tabular}{|c|c|c|c|c|c|c|c|c|c|c|}
\hline \multirow{2}{*}{ Breeds } & \multirow{2}{*}{$\mathrm{n}$} & \multicolumn{3}{|c|}{ Genotype Freq. (\%) } & \multirow{2}{*}{$\chi^{2}$} & \multirow{2}{*}{$\chi_{0.01(8)}^{2}$} & \multicolumn{2}{|c|}{ Gene Freq. (\%) } & \multirow{2}{*}{$\chi^{2}$} & \multirow{2}{*}{$\chi^{2}{ }_{0.01(4)}$} \\
\hline & & AA & $\mathrm{AB}$ & BB & & & $\mathrm{A}$ & $\mathrm{B}$ & & \\
\hline M & 18 & 0 & 0 & 100.0 & & & 0 & 100.00 & & \\
\hline $\mathrm{S}$ & 21 & 23.8 & 66.7 & 9.5 & & & 57.15 & 42.85 & & \\
\hline LS & 16 & 18.8 & 43.7 & 37.5 & $41.98^{* *}$ & 20.09 & 40.65 & 59.35 & $34.26^{* *}$ & 13.28 \\
\hline YS & 14 & 21.4 & 42.9 & 35.7 & & & 42.85 & 57.15 & & \\
\hline DLY & 24 & 29.2 & 54.2 & 16.6 & & & 56.30 & 43.70 & & \\
\hline
\end{tabular}

M - Meishan; S - Sutai; LS - Landrace $\times$ Sutai; YS - Yorkshire $\times$ Sutai; DLY - Duroc $\times$ Landrace $\times$ Yorkshire $* \chi_{\alpha(d f)}^{2}$ is the $\chi^{2}$ value where $\alpha$ is the level of significance and $d f$ degrees of freedom

$* *$ mean frequencies differ significantly at $\mathrm{P}<0.01$

Table 5 The $\chi^{2}$ test of MC4R gene and genotype frequencies in the Meishan and four other pig populations

\begin{tabular}{|c|c|c|c|c|c|c|c|c|}
\hline \multirow{2}{*}{ Population } & \multicolumn{4}{|c|}{ Genotype frequency } & \multicolumn{4}{|c|}{ Gene frequency } \\
\hline & $\mathrm{S}$ & LS & YS & DLY & $\mathrm{S}$ & LS & YS & DLY \\
\hline M & $31.77 * *$ & $15.94 * *$ & $16.10^{* *}$ & $28.68^{* *}$ & $27.10^{* *}$ & $15.56^{* *}$ & $16.28^{* *}$ & $27.36^{* *}$ \\
\hline $\mathrm{S}$ & & 4.25 & 3.74 & 0.84 & & 1.37 & 0.86 & 0.02 \\
\hline LS & & & 0.03 & 2.31 & & & 0.01 & 1.31 \\
\hline YS & & & & 1.79 & & & & 0.80 \\
\hline
\end{tabular}

M - Meishan; S - Sutai; LS - Landrace $\times$ Sutai; YS - Yorkshire $\times$ Sutai; DLY - Duroc $\times$ Landrace $\times$ Yorkshire $\chi^{2}$ values at 0.05 or 0.01 levels of significance with different degree of freedoms are as follows:

$\chi_{0.05(2)}^{2}=5.99 ; \chi_{0.01(2)}^{2}=9.21 ; \chi_{0.05(1)}^{2}=3.84 ; \chi_{0.01(2)}^{2}=6.63$

$* *$ mean frequencies differ significantly at $\mathrm{P}<0.01$

The frequencies of the MC4R gene and genotype are shown in Table 4 and the results of $\chi^{2}$ test between populations are shown in Table 5. According to these tables, the frequencies of the MC4R gene and genotype were different $(\mathrm{P}<0.01)$ in the five populations. Further, the frequencies differed $(\mathrm{P}<0.01)$ between Meishan and other populations, but the differences were not significant $(\mathrm{P}>0.05)$ between the Sutai, Landrace $\times$ Sutai, Yorkshire $\times$ Sutai and Duroc $\times$ Landrace $\times$ Yorkshire. The B allele is associated with intake and backfat thickness in the Duroc population (Kim et al., 1998), but only B alleles existed in the 
Meishan. The frequencies of A and B alleles in the other four populations were almost equal. This suggests that the frequencies of the MC4R gene and genotype changed during the development of the Sutai.

ADD1 gene: The PCR-SSCP results of the ADD1 gene are shown in Figure 3, in which the AA genotype has three bands, the BB three bands and the AB six bands. The frequencies of the ADD1 gene and genotype are shown in Table 6. Neither genotype frequencies nor gene frequencies differed significantly $(\mathrm{P}>0.05)$.

Table 6 The ADD1 gene and genotype frequencies in the Meishan and four other pig populations in China

\begin{tabular}{|c|c|c|c|c|c|c|c|c|c|c|}
\hline \multirow{2}{*}{ Population } & \multirow{2}{*}{$\mathrm{n}$} & \multicolumn{3}{|c|}{ Genotype Freq. (\%) } & \multirow{2}{*}{$\chi^{2}$} & \multirow{2}{*}{$\chi_{0.05(8)}^{2}$} & \multicolumn{2}{|c|}{ Gene Freq. (\%) } & \multirow{2}{*}{$\chi^{2}$} & \multirow{2}{*}{$\chi_{0.05(4)}^{2}$} \\
\hline & & $\mathrm{AA}$ & $\mathrm{AB}$ & BB & & & $\mathrm{A}$ & $\mathrm{B}$ & & \\
\hline $\mathrm{M}$ & 18 & 27.8 & 50.0 & 22.2 & & & 52.80 & 47.20 & & \\
\hline $\mathrm{S}$ & 21 & 23.8 & 52.4 & 23.8 & & & 50.00 & 50.00 & & \\
\hline LS & 16 & 43.7 & 37.5 & 18.8 & 9.75 & 15.51 & 62.45 & 37.55 & 8.57 & 9.49 \\
\hline YS & 14 & 57.1 & 28.6 & 14.3 & & & 71.40 & 28.60 & & \\
\hline DLY & 24 & 16.7 & 45.8 & 37.5 & & & 39.60 & 60.40 & & \\
\hline
\end{tabular}

M - Meishan; S - Sutai; LS - Landrace $\times$ Sutai; YS - Yorkshire $\times$ Sutai; DLY - Duroc $\times$ Landrace $\times$ Yorkshire

$* \chi_{\alpha(d f)}^{2}$ is the $\chi^{2}$ value where $\alpha$ is the level of significance and $d f$ degrees of freedom

\section{Conclusion}

The gene and genotype frequencies of the H-FABP and the MC4R genes differed significantly among the five pig populations in China. Only the AA genotype of the H-FABP gene and the BB genotype of the MC4R gene were found in the Meishan. This result shows that the Meishan has a special genetic composition, which could be one of the reasons for its good meat quality (Gerbens et al., 1997; Seeley et al., 1997; Kim et al., 1998; Gerbens et al., 1999; 2000). Therefore, the Meishan pig should be conserved as a valuable genetic resource.

Although the Sutai was developed from the cross between the Duroc (50\%) and the Meishan (50\%), the gene and genotype frequencies of the H-FABP and the MC4R genes differed significantly between the Meishan and Sutai populations. The BB genotypes of the H-FABP gene and the AA genotypes of the MC4R gene in the Sutai are suggested to be from the Duroc, in which these two genotypes have been found (Gerbens et al., 1999; Kim et al., 2000; Lin et al., 2002).

The traditional selection method in the development of a new breed or line is based on phenotypic information and not on genotypic information. The result of this research shows that this method cannot identify favoured genes effectively, but that MAS may have that potential.

\section{Acknowledgements}

This work was supported by the National Basic Research Program of China (No. 2004CB117502) and the Shanghai Municipal Key Project of Agriculture Science and Technology (No.2003.01-1).

\section{References}

Briggs, M.R., Yokoyama, C., Wang, X., Brown, M.S. \& Goldstein, J.L., 1993. Nuclear protein binds sterol regulatory element of low density lipoprotein receptor promoter. I. Identification of the protein and delineation of its target nucleotide sequence. J. Biol. Chem. 268, 14490-14496.

Brown, M.S. \& Goldstein, J.L., 1997. The SREBP pathway: Regulation of cholesterol metabolism by proteolysis of membrane bound transcription factor. Cell 89, 331-340.

Chakravarty, K., Leahy, P. \& Becard, D., 2001. Sterol Regulatory Element Binding proteins-1c mimics the negative effect of insulin of phosphoenolpyruvate carboxykinase (GTP) gene transcription. J. Biol. Chem. 276, 38416-38423.

Chen, M. \& Wand, A.G., 2004. Different allele frequencies of MC4R gene variants in Chinese pig Breeds. Archiv Fur Tierzucht-Archives of Animal Breeding 47 (5), 463-468. 
Dekkers, J.C., 2004. Commercial application of marker- and gene-assisted selection in livestock: strategies and lessons. J. Anim. Sci. 82 (E-Suppl.), E313-E328.

Du, R.Q., 2003. Biostatistics (2nd ed.). Higher Education Press, China.

Emnett, R., Moeller, S., Irvin, K. \& Rothschild, M.F., 2000. An investigation into the genetic controls of pork quality. Proc. $25^{\text {th }}$ Anniversary of the NSIF Conference, USA.

Foretz, M., Guichard, P. \& Ferre, P., 1999. SREBP-1c is a major mediator of insulin action on the hepatic expression of gluckinase and lipogenesis related genes. Proc. Natl. Acad. Sci. USA. 96, 12737-12742.

Gerbens, F., Koning, D.J., Harders, F.L., Meuwissen, T.H. \& Janss, L.L., 2000. The effect of adipocyte and heart fatty-acid-binding-protein genes on intramuscular fat and backfat content in Meishan crossbreds. J. Anim. Sci. 78, 552-559.

Gerbens, F., Rettenberger, G., Lenstra, J.A., Veerkamp, J.H. \& te Pas, M.F.W., 1997. Characterization, chromosomal localization and genetic variation of the porcine heart fatty acid-binding protein gene. Mamm. Genome 8, 328-332.

Gerbens, F., Van Erp, A.J., Harders, F.L., Verburg, F.J., Meuwissen, T.H., Veerkamp, J.H. \& te Pas, M.F.W., 1999. Effect of genetic variants of the heart fatty acid-binding protein gene on intramuscular fat and performance traits in pigs. J. Anim. Sci. 77, 846-852.

Hitoshi, S., 2001. Sterol regulatory element-binding proteins (SREBPs): transcriptional regulators of lipid synthetic genes. Progress in Lipid Res. 40 (6), 439-452.

Kim, J.B., Margaret, P.S., Wright, K.M., Yao, E.M., Gemma, S., Bradford, B.L. \& Bruce, M.S., 1998. Nutritional and insulin regulation of fatty acid synthetase and leptin gene expression through ADD1/SREBP1. J. Clin. Invest. 101 (1), 1-9.

Kim, K.S., Larsen, N., Short, T., Plastow, G. \& Rothschild, M.F., 2000. A missense variant of the porcine melanocortin-4 receptor (MC4R) gene is associated with fatness, growth, and feed intake traits. Mammalian Genome 11, 131-135.

Le Lay, S., Lefrere, I., Trautwein, C., Dugail, I. \& Krief, S., 2002. Insulin and sterol-regulatory elementbinding protein-1c (SREBP-1c) regulation of gene expression in 3T3-L1 adipocytes. Identification of CCAAT/enhancer-binding protein beta as an SREBP-1C target. J. Biol. Chem. 38, 35625-35634.

Lin Wan-hua, Huang Lu-sheng, Ren Jun, Deng Su-hua, Wang Wen-jun, Liu Bao-sheng, Zhou Li-hua \& Cheng Cong-ying, 2002. Research on genetic variation of heart fatty acid binding protein in ten pig breeds. Acta Genetica Sinica 29 (1), 12-15.

Sambrook, J., Fritsch, E.F. \& Maniatis, T., 2002. Molecular Cloning: A Laboratory Manual (2nd ed.), Science Press, China.

SAS, 1994. Statistical Analysis Systems user's guide (Version 6, 12). SAS Institute Inc., Cary, N.C., USA.

Seeley, R.J., Yagaloff, K.A. \& Fisher, S.L., 1997. Melanocortin receptors in leptin effects. Nature 390, 349.

Yokoyama, C., Wang, X., Briggs, M.R., Admon, A., Wu, J., Hua, X., Glodstein, J.L. \& Brown, M.S., 1993. SREBF1, a basic helix-loop-helix leucine zipper protein that controls transcription of the LDL receptor gene. Cell 75, 187-197. 